\title{
Nutrient Cycling and Soil Health in Organic Cropping Systems - Importance of Management Strategies and Soil Resilience
}

\author{
Derek H. Lynch ${ }^{1}$ \\ ${ }^{1}$ Faculty of Agriculture, Dahousie University, Truro, Canada \\ Correspondence: Derek H. Lynch, Department of Plant and Animal Sciences, Faculty of Agriculture, Dalhousie \\ University, Truro, NS, B2N 5E3, Canada. Tel: 1-902-893-7621. E-mail: Derek.lynch@dal.ca
}

Received: February 16, 2015 Accepted: May 3, 2015 Online Published: June 20, 2015

doi:10.5539/sar.v4n3p80 URL: http://dx.doi.org/10.5539/sar.v4n3p80

\begin{abstract}
Organic field crop systems are characterized by complex rotations with high spatial and temporal vegetative diversity, an enhanced use of legumes, and reduced external nutrient (nitrogen $(\mathrm{N})$ and phosphorus $(\mathrm{P})$ ) use. At the same time, a core premise of certified organic agriculture is that this farming system provides benefits to soil health via enhanced microbial diversity. The following short review, drawing primarily upon selected studies from North America, examines the impact of farming systems, and various management strategies within these, on soil organic matter, $\mathrm{N}$ and $\mathrm{P}$ dynamics, and soil microbial and macrofaunal abundance and diversity. Organic cropping systems are shown to provide benefits with respect to reduced farm $\mathrm{N}$ and $\mathrm{P}$ surpluses, in combination with maintenance of soil organic matter and improved soil health. However, soil health benefits appear consistently achieved only for larger soil organisms partly due to the resilience of the soil microbial community. Recent research examining soil $\mathrm{P}$ dynamics and $\mathrm{P}$ uptake in relation to legume biological $\mathrm{N}_{2}$ fixation and bacterial and mycorrhizal community diversity provide evidence of the resilience of the soil microbial community with respect to functionality, if not diversity of microbial community composition. These latter results may challenge organic agriculture core premises of consistent benefits to soil health via enhanced microbial diversity, but in its place may lead to an improved understanding of how specific cropping practices and production system intensity overall, rather than farming system per se, influences both nutrient cycling and soil ecosystem functioning.
\end{abstract}

Keywords: organic agriculture, soil health, soil fertility, microbial diversity, soil resilience

\section{Introduction}

A core premise of certified organic agriculture is that this farming system benefits soil health via enhanced microbial diversity, with ancillary benefits with respect to soil quality, nutrient dynamics and broad farm ecology generally (Stockdale \& Watson, 2009; Gomiero et al., 2011). But what do we mean by soil health? Faced with growing evidence of the remarkable resilience especially of the soil microbial community, however, - is soil microbial diversity per se a key goal or is it more appropriate and beneficial to focus on the abundance and diversity of higher trophic levels? Postma-Blaauw et al. (2010) for example, found the abundance of taxonomic groups such as earthworms, microarthropods and nematodes was much more affected by agricultural intensification than that of bacteria, fungi and protozoa. Is the primary interest of organic farming systems in soil biota diversity or in its functioning, and as relates to the farm ecosystem or broader ecological intensification? Finally, are 'farming systems', that is, certified organic versus conventional production, the dominant driving factor or is the intensity of management, whether within organic or other production systems, a more important determinant of soil and nutrient dynamics?

The following short review is designed to offer reflection, and hopefully generate a discussion, on these important questions. This may challenge the organic agriculture premise of consistent benefits to soil health via enhanced microbial diversity, but in its place lead to an improved understanding of how soil microbial resilience, and production system intensity and specific cropping practices, rather than farming system per se, influence these important soil system outcomes. Such an improved understanding of plant and soil biota relationships as influenced by farming practices will provide a more refined framework for approaches to beneficial management of these relationships and their influence on nutrient dynamics and efficiency and farming system productivity.

The following review draws upon recent reviews and ongoing field research by the author and colleagues with a 
primary, but not exclusive, focus on organic cropping systems in North America, and with respect to nutrients, a particular focus on nitrogen $(\mathrm{N})$ and phosphorus $(\mathrm{P})$ dynamics in relation to soil health.

\section{Linking Nutrient and Soil Management in Organic Cropping Systems}

The challenge of balancing agricultural productivity with provision of key ecosystems services (soil and water quality; conservation of pollinator communities, biodiversity and biological pest control; climate regulation etc.) has led to calls for 'ecological intensification' and agricultural system redesign (Cassman, 1999; Swinton et al., 2007; Drinkwater, 2009, Reganold et al., 2011). Organic farming takes the perspective that the preservation and enhancement of soil quality and health through optimized farm management practices is the critical underpinning to maintaining system productivity while also achieving a balance with maintenance of diversity and provision of key ecosystem services. Studies, primarily from Europe, indicate organic farming promotes vegetative diversity, often accompanied by other facets of belowground and aboveground diversity (Bengtsson et al., 2005; Hole et al., 2005; Gomiero et al. 2011; Tuck et al., 2014). The limited relevant scientific literature of Canadian and US origin also suggest that among taxa, vegetative diversity is most consistently influenced by farming system. This benefit of organic farming has sometimes also been found, depending on management of non-crop habitat and the complexity of the surrounding landscape, to extend to other taxa (Boutin et al., 2008; Lynch et al., 2012a; Girard et al., 2014).

\subsection{Soil Organic Matter and Soil Biota}

In recent years there has been increasing interest in determining whether organic cropping systems enhance soil organic matter (SOM) levels, or at least reduce losses in SOM, when compared with conventional production systems. This interest is driven by acknowledgement of the central role of SOM in soil quality and health, productivity and ecosystem services goals, concerns regarding the impact of continued use of tillage in organic farming on SOM, along with an interest in having organic farming potentially acknowledged as a means of enhancing C sequestration in soil. In a recent review, Lynch (2014) presented results of comparative SOM levels from some of the best long-term comparative farming systems trials in North America (Table 1), along with selected studies from elsewhere. Allowing for acknowledgement of the complexity and methodological challenges inherent in such comparisons, which were also discussed, the consensus of the data suggests that organic field crop production at least sustains SOM when compared with conventional systems. A meta-analysis of changes in soil organic carbon (SOC) stocks with organic farming using data from 74 long-term studies, similarly found that when the dataset was restricted to those studies reporting external $\mathrm{C}$ and $\mathrm{N}$ inputs and soil bulk densities, farming systems (organic and non-organic) failed to differ in topsoil $\mathrm{C}$ sequestration rates (Gattinger et al., 2012).

Broad comparisons of SOM stocks may hide important system differences of relevance. Indeed the data are perhaps more persuasive regarding the benefits of organic systems in enhancing the quality, if not the quantity of $\mathrm{SOM}$, and in particular the labile pools of SOM, including the microbial biomass and particulate SOM - the turnover of which provides nutrients and energy for crop and wider ecosystem benefits. For example, a study in Denmark found that although four-different organic management regimes (varying in manure, green manure and catch crop use) returned $\mathrm{C}$ to soil at levels $18-91 \%$ greater than conventional cropping, SOC levels after 11 years were the same for all systems (Chirinda et al., 2010). However, in the organic system microbial biomass and activity (respiration) increased correspondingly with the greater return of $\mathrm{C}$, evidence of a more biologically active soil. Many studies have shown enhanced labile SOM (particulate organic matter (POM) etc.) fractions under organic than under conventional management regimes (Marriot \& Wander, 2006; Lynch, 2014). In this regard organic systems may be considered closer to achieving the balanced approach to management of soil $\mathrm{C}$ as proposed by Canadian soil scientist H. Janzen in his elegant paper 'The soil carbon dilemma:shall we hoard it or use it' (Janzen, 2006). That is, how to store C in soil while also 'feeding the soil' with inputs of energy and nutrients for the soil biota to provide both crop and broader ecosystem benefits. As elaborated further below, changes to soil quality and microbial abundance and activity do not necessarily correspond with concomitant changes in soil microbial diversity per se. In addition, both with respect to nutrient flows and soil health, differences between management approaches and practices within a farming system, along with temporal variation, may be as important as determining factors than are differences between farming system (organic versus conventional) per se. Finally, the relative response of higher trophic levels in soil to the influence of farming system may differ notably from that of the soil microbial community (Postma-Blaauw et al., 2010).

The abundance and diversity of higher tropic level organisms (beetles, earthworms, spiders etc.) appear particularly sensitive to the enhanced spatial and temporal diversity of organic farming systems. In horticultural systems, use of mulches and approaches to weed management may result in even greater modifications in the 
quantity and quality of soil organic matter which in turn influence nutrient dynamics and soil biota. In highbush blueberry systems in Atlantic Canada, mulch type and quality substantially influenced weed community and abundance, $\mathrm{N}$ dynamics and crop productivity (Burkhard et al., 2009). Subsequent research documented how ground floor management (mulching and or weeding) in highbush blueberry systems, shifted Carabidae and Staphylinidae diversity and potential for biological control of immature blueberry maggot (Renkema et al., $2012 \mathrm{a}, \mathrm{b}$ ). Under the extended (5-year) rotations common to organic potato production in Atlantic Canada, microbial quotient (microbial biomass $\mathrm{C}$ as a fraction of total SOC) and earthworms recovered from a sharp decrease during the potato phase of the rotation to levels of undisturbed pasture reference sites (Nelson et al., 2009). A novel laboratory-based test using the Collembola bioindicator (Folsomia candida) confirmed a positive response to the greater POM and microbial biomass found under such organic potato, but not conventional, potato production systems (Nelson et al., 2011). Recent research in Ontario by Girard et al. (2014) found the greater food biomass (arthropods etc.) for nestlings (young songbirds) in organic than conventional soybean fields was attributable specifically to the longer rotations found in the organic production systems.

Zero tillage of green manures (using a roller crimper) is a relatively new technology recently being evaluated for organic field crop production in North America. While the agronomic benefits of this novel approach to management of green manures are increasingly being assessed (Vaisman et al., 2011; Mirsky et al., 2012), the impact on soil biology and plant-microbe relations remains relatively unexplored. It has been suggested that roller crimping of green manures may further enhance benefits for earthworms and larger soil organisms as a result of the modification of the surface soil environment by the large volume of green manure mulch retained on the soil surface (up to $8 \mathrm{Mg} \mathrm{ha}^{-1}$ ) (Marshall, 2014). In contrast to Europe the wider ecological impact of vegetative complexity of crops and field margins as influenced by organic versus conventional management and landscape complexity on arthropods generally, and native pollinator abundance and diversity, remains relatively unexamined in North America. While the above review suggests soil health may benefit from organic management, depending on cropping system, at the soil microbial level, functional groups such as decomposers appear to exhibit a high degree of resilience to farming system influences (Postma-Blaauw et al., 2010; Lynch et al., 2014; Tuck et al., 2014). The implications of such microbial resilience (i.e. stability and resistance to change of microbial community composition) with respect to $\mathrm{N}$ and especially $\mathrm{P}$ dynamics are discussed further below.

Table 1. Comparison of soil organic carbon storage of organic (Org) and conventional (Conv) field cropping systems from long-term comparative field trials

\begin{tabular}{|c|c|c|c|c|c|c|}
\hline Authors & Region & $\begin{array}{l}\begin{array}{l}\text { Study } \\
\text { (years) }\end{array}\end{array}$ & Period & Org $<$ Conv & Org $=$ Conv & Org $>$ Conv \\
\hline Mahli et al. 2009 & Canada & 12 & & & $\sqrt{ }$ & \\
\hline Bell et al. 2012 & Canada & 18 & & $13-15 \%^{1}$ & & \\
\hline Pimentel et al. 2005 & US & 22 & & & & $20-25 \%^{2}$ \\
\hline Teasdale et al. 2007 & US & 9 & & & & $19 \%^{3}$ \\
\hline Wortman et al. 2011 & US & 11 & & & $\sqrt{ }$ & \\
\hline Robertson et al. 2000 & US & 8 & & $12 \%$ & & \\
\hline Leifeld et al. 2009 & Switzerland & 27 & & & $\sqrt{ }$ & \\
\hline Kirchmann et al. 2007 & Sweden & 18 & & & & $16 \%$ \\
\hline Chirinda et al. 2010 & Denmark & 11 & & & $\sqrt{ }$ & \\
\hline
\end{tabular}

${ }^{1}$ SOC stocks reported to $120 \mathrm{~cm}$ depth. Differences between farming systems were smaller for the alfalfa/crop (13\%) compared to annual crop $(15 \%)$ rotations. ${ }^{2}$ Higher gains $(25 \%)$ were recorded for the 'organic animal' then 'organic legume' (20\%) system ${ }^{3}$ Compared to a no-till treatment. Adapted from Lynch (2014) with permission of Taylor and Francis Group, LLC, a division of Informa plc. Copyright 2014 from Managing Energy, Nutrients, and Pests in Organic Field Crops by R.C. Martin and R. MacRae (Eds). 


\subsubsection{Nutrient Dynamics and Efficiency as Influenced by Cropping System Management}

Legume-derived $\mathrm{N}$ from biological $\mathrm{N}_{2}$ fixation (BNF) is critical to the sustainability of organic crop (annual and perennial) production systems on commercial farms (Woodley et al., 2014), and contributes substantially to sustainability with respect to reduced energy use on organic farms (Lynch et al., 2011). However, productivity and nutrient $(\mathrm{N}$ and $\mathrm{P})$ loading and risk of losses, and nutrient use efficiency from organic production systems can vary with specific management practices and overall farm intensity of production; furthermore seasonal variation affects soil $\mathrm{N}$ mineralization and potential synchrony of soil available $\mathrm{N}$ supply with cash crop demand (Lynch et al., 2012a,b). In Denmark, three vegetable plus cereal organic cropping systems varied in autumn catch crops, green manures and intercrops (Thorup-Kristensen et al., 2012). In this study, the green manures when present in a rotation doubled soil exploration by roots, which reduced $\mathrm{N}$ leaching. It has been demonstrated that while organic potato yields were lower $(\sim 20 \%)$ when compared with those maintained under a conventional fertilization regime, nitrogen use efficiency (NUE; measured as tuber yield per unit crop $\mathrm{N}$ uptake) was higher for the organically managed crops (Lynch et al., 2012b). This is in agreement with findings in Europe (Möller et al., 2007). In contrast a long-term (18 year) cropping systems study in Sweden found NUE was lower for the organic crop management regime (Kirchmann et al., 2007). Agronomic strategies and tools to further improve management of N and NUE in organic cropping are increasingly being examined. For example, the in situ use of anion and cation exchange probes have been used to predict soil $\mathrm{N}$ availability in potato production (Sharifi et al., 2009).

\subsubsection{The Issue of Phosphorus}

A growing body of literature has reported low $\left(<10 \mathrm{mg} \mathrm{kg}^{-1}\right)$ soil test phosphorus (STP) levels for Canadian organic crop and livestock sectors (Entz et al., 2001; Martin et al., 2007; Roberts et al., 2008; Knight et al., 2010; Main et al., 2013). Such low bioavailable P levels suggest potential crop P deficiencies have potential to negatively impact on yields, legume biological $\mathrm{N}_{2}$ fixation (BNF) and overall farm productivity and sustainability. Application of rock phosphate and approaches such as green manure phytoextraction of rock phosphate $\mathrm{P}$ has been found to be inadequate for enhancing soil $\mathrm{P}$ supply on the predominantly alkaline soils in much of these cropping regions (Arcand et al., 2010). Appropriate sources and volumes of manure, particularly in western Canada are largely unavailable (Woodley et al., 2014). However, as noted above with respect to NUE, farm P status within specific organic sectors varies significantly with organic management strategies and intensity of production. Three distinct groupings of commercial organic dairy farms were identified in Ontario (Roberts et al., 2008). Their very different management strategies represented a spectrum from targeting feed self-sufficiency as a priority to other organic dairy farms where the goal was to maximize productivity. These variations in intensity of organic management strongly impacted not only farm livestock density (livestock units $\mathrm{ha}^{-1}$ ) but also on whole-farm N, P and K nutrient surpluses and efficiencies. In more recent work on many of the same dairy farms the relationship between STP (and forage (alfalfa/grass mixtures) productivity and BNF (Main et al., 2013) showed that forage yields and BNF were not inversely related to STP levels in these long-term organically managed soils. This indicates biological and biochemical solubilization of soil organic $\mathrm{P}$, and a likely enhanced role for arbuscular mycorrhizal fungi (AMF), play an important role in these systems.

\section{Soil Health and Nutrient Dynamic Linkages as Influenced by Production System}

Soil health is defined as 'the capacity of soil to function as a vital living system, within ecosystem and land-use boundaries, to sustain plant and animal productivity, maintain or enhance water and air quality, and promote plant and animal health' (Doran \& Zeiss, 2000). Soil organisms, including the abundance and diversity of bacteria, fungi, and nematodes, are considered key indicators of changes in soil health as they 'respond sensitively to anthropogenic disturbance' (Doran \& Zeiss, 2000). Our recent reviews, and research from long-term experiments and paired organic versus conventional farming systems, however, suggests a high degree of resilience of soil microbial community diversity to farming system management, when compared to the influence of temporal shifts or specific crop sequence influences (Postma-Blaauw et al., 2010; Lynch, 2014). For example, studies conducted within the long-term DOK trials in Switzerland have found bacterial community structure (Widmer et al., 2006) and fungal community structure (Schneider et al., 2010) to be more influenced by temporal effects and individual crops than farming system per se. In the US, Kong and Six (2012) tracked the microbial turnover and assimilation of 13C-labelled hairy vetch root tissue as affected by 14 years of conventional, organic or low-input crop production. Using PLFA techniques they found the soil microbial community structure processing the incoming root $\mathrm{C}$ was similar across all farming systems.

Functional properties, however, such as enhanced biochemical and biological turnover of organic phosphorus, appear to be enhanced by organic farming systems, and may contribute to enhanced phosphorus use efficiency 
(PUE) in these systems. While the mechanisms involved remain poorly understood it may entail legumes influencing not only the abundance (root colonization), but also the community composition, of AMF. In Western Canada, even under conventional management and high STP, legume roots (of lentil and peas) can host a richer, more diverse, and even AMF community compared to wheat roots (Bainard et al., 2014). Higher soil microbial richness in organic wheat systems in Alberta has been attributed to be partially due to greater prevalence of weeds in these systems, however mycorrhizal fungi were not promoted as most weeds in that study were non-mycorrhizal (Nelson et al., 2011b). Although wheat yields were lower, the Claroideoglomus genus of AMF was found to be more prevalent in organic wheat fields, and was associated with enhanced wheat PUE by Dai et al. (2014). Under controlled conditions C. claroideum enhanced legume (Medicago trunculata) PUE (Lendenmann et al., 2011) while Wagg et al. (2011) suggested C. claroideum provides a competitive advantage to legumes. Houlton et al. (2008) suggested legumes ability to support soil phosphatase enzyme activity is another key strategic evolutionary advantage in low P status soils, although a strong body of evidence to support this hypothesis has not yet been produced.

Our recent research (Fraser et al., 2015) examined alkaline phosphatase enzyme activity and bacterial phoD gene abundance as influenced by long-term management at the Glenlea long-term (20 years) rotation study of the University of Manitoba, which includes an Organic - no inputs system (ORG); an Organic with manure application in 2007 (ORG-M) (not discussed further here); a Conventional (CON) production system each maintained under a four year rotation of flax-alfalfa-alfalfa-wheat. An additional system examined included restored native prairie (PRA). The STP levels in each system were greater in the CONV $\left(19.3 \mathrm{mg} \mathrm{kg}^{-1}\right)$ and PRA system $\left(29.6 \mathrm{mg} \mathrm{kg}^{-1}\right)$ than for the ORG $\left(7.6 \mathrm{mg} \mathrm{kg}^{-1}\right)$, attributable to the history of export of alfalfa from this system with no manure returned. However, alkaline phosphatase (ALP) activity was higher in the ORG soils with lower bioavailable P. In spite of lower bacterial diversity ( $p h o D$ community structure) and low STP level under the organic cropping regime, $p h o D$ gene expression was positively correlated with alkaline phosphatase enzyme activity (ALP), and was higher in the organic farming systems when compared with prairie or conventional cropping. Thus, while these results indicated higher bacterial diversity in conventional soils, this diversity was not critical for maintenance of the important soil functions that relate to biochemical and biological turnover of organic phosphorus.

\section{Conclusions}

The distinctiveness of organic systems (legumes, vegetative diversity, high $\mathrm{C}$ but low $\mathrm{P}$ inputs etc.) is advancing our scientific understanding, and opportunities to manage, plant and soil microbial relations for improved nutrient cycling and ecosystem health. These farming systems are adept at promoting soil life generally. In light of recent research, however, there is a need to refine what might be considered organic agriculture core premises of consistent benefits to soil health including enhanced microbial diversity. This should be replaced with a more refined understanding of how specific cropping practices and intensity of production, rather than necessarily farming system per se, influences both nutrient cycling and soil ecosystem functioning. An improved understanding of these edaphic, agronomic and agro-ecological impacts of organic cropping strategies, and their inherent tradeoffs with productivity, can only lead to improved management overall.

\section{Acknowledgements}

Funding in support of the oral presentation of this paper by the author and provided by the Organisation for Economic Co-operation and Development (OECD) Co-operative Research Programme on Biological Resource Management for Sustainable Agricultural Systems, USDA-NIFA and ICROFS is gratefully acknowledged. Core funding for the authors research program is provided by the Canada Research Chairs program.

\section{References}

Arcand, M. M., Lynch, D. H., Voroney, R. P., \& van Straaten, P. (2010). Residues from a buckwheat (Fagopyrum esculentum) green manure crop grown with phosphate rocks influence soil phosphorus dynamics. Canadian Journal of Soil Science, 90, 257-266. http://dx.doi.org/10.4141/CJSS09023

Bainard L. D., Bainard, J. D., Hamel, C., \& Gan, Y. T. (2014). Spatial and temporal structuring of arbuscular mycorrhizal communities is differentially influenced by abiotic factors and host crop in a semi - arid $\begin{array}{lllll}\text { prairie agroecosystem. } & \text { FEMS }\end{array}$ http://dx.doi.org/10.1111/1574-6941.12300

Bell, L. W., Sparling, B., Tenuta, M., \& Entz, M. H. (2012). Soil profile carbon and nutrient stocks under long-term conventional and organic crop and alfalfa-crop rotations and re-established grassland. Agriculture Ecosystems and Environment, 158, 156-163. http://dx.doi.org/10.1016/j.agee.2012.06.006 
Bengtsson, J., Ahnstrom, J., \& Weibull, A. C. (2005). The effects of organic agriculture on biodiversity and abundance: A meta-analysis. Journal of Applied Ecology, 42, 261-269. http://dx.doi.org/10.1111/j.1365-2664.2005.01005.x

Boutin, C., Baril, A., \& Martin, P. A. (2008). Plant diversity in crop fields and woody hedgerows of organic and conventional farms in contrasting landscapes. Agriculture Ecosystems and Environment, 123, 185-193. http://dx.doi.org/10.1016/j.agee.2007.05.010

Burkhard, N. E., Lynch, D. H., Percival, D. C., \& Sharifi, M. (2009). Organic mulch impact on vegetation dynamics and productivity of highbush blueberry under organic production. Hortscience, 44, 1-9.

Cassman, K. (1999). Ecological intensification of cereal production systems: yield potential, soil quality and precision agriculture. Proceedings of the National Academy of Sciences, 96, 5952-5959. http://dx.doi.org/10.1073/pnas.96.11.5952

Chirinda, N., Olesen, J. E., Porter, J. R., \& Schjønning, P. (2010). Soil properties, crop production and greenhouse gas emissions from organic and inorganic fertilizer-based arable cropping systems. Agriculture Ecosystems and Environment, 139, 584-94. http://dx.doi.org/10.1016/j.agee.2010.10.001

Dai, M., Hamel, C., Bainard, L. D., St. Arnaud, M., Grant, C. A., Lupwayi, N. Z, .. Lemke, R. (2014). Negative and positive contributions of arbuscular mycorrhizal fungal taxa to wheat production and nutrient uptake efficiency in organic and conventional systems in the Canadian prairie. Soil Biology and Biochemistry, 74, 156-166. http://dx.doi.org/10.1016/j.soilbio.2014.03.016

Doran, W. J., \& Zeiss, M. R. (2000). Soil health and sustainability: Managing the biotic component of soil quality. Applied Soil Ecology, 15, 3-11. http://dx.doi.org/10.1016/S0929-1393(00)00067-6

Drinkwater, L. E. (2009). Ecological knowledge: Foundation for Sustainable Organic Agriculture. In C. Francis (Ed.). Organic Farming: The Ecological System (pp. 19-47). American Society of Agronomy, Madison, WI. http://dx.doi.org/10.2134/agronmonogr54.c2

Entz, M. H., Guilford, R., \& Gulden, R. (2001). Crop yield and soil nutrient status on 14 organic farms in the eastern portion of the northern great plains. Canadian Journal of Plant Science, 81, 351-354. http://dx.doi.org/10.4141/P00-089

Fraser, T., Lynch, D. H., Entz, M., \& Dunfield, K. (2015). Linking alkaline phosphatase activity with bacterial phoD gene abundance in soil from a longterm management trial. Geoderma.

Gattinger, A., Muller, A., Haeni, M., Skinner, C., Fliessbach, A., Buchmann, N., ... Niggli, U. (2012). Enhanced top soil carbon stocks under organic farming. Proceedings of the National Academy of Sciences, 109, 18226-18231. http://dx.doi.org/10.1073/pnas.1209429109

Girard, J. Mineau, P., \& Fahrig, L. (2014). Higher nestling food biomass in organic than conventional soybean fields in eastern Ontario, Canada. Agriculture Ecosystems and Environment, 189, 199-205. http://dx.doi.org/10.1016/j.agee.2014.03.033

Gomiero, T., Pimental, D., \& Paoletti, M. G. (2011). Environmental impact of different agricultural management practices: Conventional vs. organic agriculture. Critical Reviews in Plant Sciences, 30, 95-124. http://dx.doi.org/10.1080/07352689.2011.554355

Hole, D. G., Perkins, A. J., Wilson, J. D., Alexander, I. H., Grice, P. V., \& Evans, A. D. (2005). Does organic

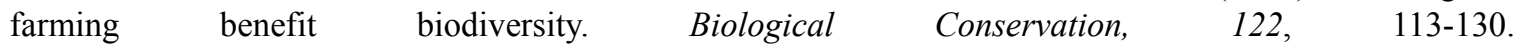
http://dx.doi.org/10.1016/j.biocon.2004.07.018

Houlton, B. Z, Wang, Y., Vitousek, P. M., \& Field, C. B. (2008). A unifying framework for dinitrogen fixation in the terrestrial biosphere. Nature, 454, 327-330. http://dx.doi.org/10.1038/nature07028

Janzen, H. H. (2006). The soil carbon dilemma: Shall we hoard it or use it? Soil Biology and Biochemistry, 38, 419-424. http://dx.doi.org/10.1016/j.soilbio.2005.10.008

Kirchmann, H., Bergstrom, L., Katterer, T., \& Gesslein, S. (2007). Comparison of long-term organic and conventional crop-livestock systems on a previously nutrient-depleted soil in Sweden. Agronomy Journal, 99, 960-72. http://dx.doi.org/10.2134/agronj2006.0061

Knight, J. D., Buhler, R., Leeson, J. Y., \& Shirtliffe, S. J. (2010). Classification and fertility status of organically managed fields across Saskatchewan, Canada. Canadian Journal of Soil Science, 90, 667-678. http://dx.doi.org/10.4141/cjss09082 
Kong, A. Y. Y., \& Six, J. (2012). Microbial community assimilation of cover crop rhizodeposition within soil microenvironments in alternative and conventional cropping systems. Plant and Soil, 356, 315-330. http://dx.doi.org/10.1007/s11104-011-1120-4

Leifeld, J., Reiser, R., \& Oberholzer, H. R. (2009). Consequences of conventional versus organic farming on soil carbon: results from a 27-year field experiment. Agronomy Journal, 101, 1204-18. http://dx.doi.org/10.2134/agronj2009.0002

Lendenmann., M., Thonar, C., Barnard, R. L., Salmon, Y., Werner, R. A., Frossard, E., \& Jansa, J. (2011). Symbiont identity matters: carbon and phosphorus fluxes between Medicago truncatula and different arbuscular mycorrhizal fungi. Mycorrhiza, 21, 689-702. http://dx.doi.org/10.1007/s00572-011-0371-5

Lynch, D. H., MacRae, R. J., \& Martin, R. C. (2011). The carbon and global warming potential impacts of organic farming: Does it have a significant role in an energy constrained world? Sustainability, 3, 322-362. http://dx.doi.org/10.3390/su3020322

Lynch, D. H., Halberg, N., \& Bhatta, G. D. (2012a). Environmental impacts of organic agriculture in temperate regions. CAB Reviews, 7, 1-17. http://dx.doi.org/10.1079/PAVSNNR20127010

Lynch, D. H., Sharifi, M., Hammermeister, A., \& Burton, D. (2012b). Nitrogen Management in Organic Potato Production. In H. Zhongi, R. P. Larkin \& C. W. Honeycutt (Eds.), Sustainable Potato Production: Global Case Studies. (pp. 209-231) New York: Springer Science+Business Media.

Lynch, D. H. (2014). Sustaining Soil Organic Carbon, Soil Quality and Soil Health in Organic Field Crop Management Systems. In R. C Martin \& R. MacRae (Eds.). Managing Energy, Nutrients and Pests in Organic Field Crops. (pp. 107-132) CRC Press.

Mahli, S. S., Brandt, S. A., Lemke, R., \& Zentner, R. P. (2009). Effects of input level and crop diversity on soil nitrate-N, extractable $\mathrm{P}$, aggregation, organic $\mathrm{C}$ and $\mathrm{N}$, and nutrient balance in the Canadian Prairie. Nutrient Cycling in Agroecosystems, 84, 1-22. http://dx.doi.org/10.1007/s10705-008-9220-0

Main, M., Lynch, D. H., Voroney, R. P., \& Juurlink, S. (2013). Soil phosphorus effects on forage harvested and nitrogen fixation on Canadian organic dairy farms. Agronomy Journal, 105, 1-9. http://dx.doi.org/10.2134/agronj2012.0500

Marriott, E. E., \& Wander, M. M. (2006). Total and labile soil organic matter in organic and conventional farming systems. Soil Science Society of America Journal, 70, 950-959. http://dx.doi.org/10.2136/sssaj2005.0241

Marshall, C., Lynch, D. H., \& Entz, M. (2014). Influence of intensity of tillage for green manure termination on soil health. Poster presented at 'Balancing the Trade-Off Between Productivity and Environmental Health', joint annual conference of the Canadian Society of Agronomy and Horticulture Science, July 10-12 ${ }^{\text {th }}, 2014$, Lethbridge, Alberta.

Martin, R. C., Lynch, D. H., Frick, B., \& van Straaten, P. (2007). Phosphorus status on Canadian organic farms. Journal of the Science of Food and Agriculture, 87, 2737-2740. http://dx.doi.org/10.1002/jsfa.3077

Mirsky, S. B., Ryan, M. R., Curran, W. S., Teasdale, J. R., Maul, J., Spargo, J. T., ... Camargo, G. C. (2012). Conservation tillage issues: Cover-crop based organic rotational no-till grain production in the mid-Atlantic region, USA. Renewable Agriculture and Food Systems, 27, 31-40. http://dx.doi.org/10.1017/S1742170511000457

Möller, K., Habermeyer, J., Zinkernagel. V., \& Reents, H. J. (2007). Impact and interactions of nitrogen and Phytophthora infestans as yield-limiting factors and yield reducing factors in organic potato (Solanum tuberosum L.) crops. Potato Research, 49, 281-301. http://dx.doi.org/10.1007/s11540-007-9024-7

Nelson, K. L., Lynch, D. H., \& Boiteau, G. (2009). Assessment of changes in soil health throughout organic potato rotation sequences. Agriculture Ecosystems and Environment, 131, 220-228. http://dx.doi.org/10.1016/j.agee.2009.01.014

Nelson, K. L., Boiteau, G., Lynch, D. H., Peters, R. D., \& Fillmore, S. (2011a). Influence of agricultural soils on the growth and reproduction of the bio-indicator Folsomia candida. Pedobiologica, 54, 79-86. http://dx.doi.org/10.1016/j.pedobi.2010.09.003

Nelson, A. G., Quideau, S., Frick., B., Niziol, D., Clapperton, J., \& Spaner, D. (2011b). Spring wheat genotypes differentially alter soil microbial communities and wheat breadmaking quality in organic and conventional systems. Canadian Journal of Plant Science, 91, 485-495. http://dx.doi.org/10.4141/cjps10056 
Pimentel, D., Hepperly, P., Hanson, J., Dounds, D., \& Seidel, R. (2005). Environmental, energetic, and economic comparisons of organic and conventional farming systems. Bioscience, 55, 573-82. http://dx.doi.org/10.1641/0006-3568(2005)055\%5B0573:EEAECO\%5D2.0.CO;2

Postma-Blaauw, M., de Goede, R. G. M., Bloem, J., Faber, J. H., \& Brussaard, L. (2010). Soil biota community structure and abundance under agricultural intensification and extensification. Ecology, 91, 460473. http://dx.doi.org/10.1890/09-0666.1

Reganold, J. P., Jackson-Smith D., Batie, S. S., Harwood, R. R., Kornegay, J. L., Bucks, D., ... Willis, P. (2011). Transforming US agriculture. Science, 332, 670-671. http://dx.doi.org/10.1126/science.1202462

Renkema, J. M., Lynch, D. H., Cutler, G. C., MacKenzie, K., \& Walde, S. J. (2012a). Ground and rove beetles (Coleoptera: Carabidae and Staphylinidae) are affected by mulches and weeds in highbush blueberries. Environmental Entomology, 41, 1097-1106. http://dx.doi.org/10.1603/EN12122

Renkema, J. M., Lynch, D. H., Cutler, G. C., MacKenzie, K., \& Walde, S. J. (2012b). Predation by Pterostichus melanarius (Illiger) (Coleoptera: Carabidae) on immature Rhagoletis mendax Curran (Diptera: Tephritidae) in semi-field and field conditions. Biological Control, 60, 46-53. http://dx.doi.org/10.1016/j.biocontrol.2011.10.004

Roberts, C. J., Lynch, D. H., Voroney, R. P., Martin, R. C., \& Juurlink, S. D. (2008). Nutrient budgets of Ontario organic dairy farms. Canadian Journal of Soil Science, 88, 107-114. http://dx.doi.org/10.4141/S06-056

Robertson, G. P., Paul, E. A., \& Harwood, R. R. (2000). Greenhouse gases in intensive agriculture: Contributions of individual gases to the radiative forcing of the atmosphere. Science, 289, 1922-5. http://dx.doi.org/10.1126/science.289.5486.1922

Schneider, S., Hartmann, M., Enkerli, J., \& Widmer, F. (2010). Fungal community structure in soils of conventional and organic farming systems. Fungal Ecology, 3, 215-224. http://dx.doi.org/10.1016/j.funeco.2009.10.006

Sharifi, M., Lynch, D. H., Zebarth, B. J., Zheng, Z., \& Martin, R. C. (2009). Evaluation of nitrogen supply rate measured by in situ placement of Plant Root Simulator probes as a predictor of nitrogen supply from soil and organic amendments in potato crop. American Journal of Potato Research, 86, 356-366. http://dx.doi.org/10.1007/s12230-009-9090-2

Stockdale, E. A., \& Watson, C. A. (2009). Biological indicators of soil quality in organic farming systems. Renewable Agriculture and Food Systems, 24, 308-318. http://dx.doi.org/10.1017/S1742170509990172

Swinton S. M., Lupi, F., Robertson, G. P., \& Hamilton, S. K. (2007). Ecosystem services and agriculture: Cultivating agricultural ecosystems for diverse benefits. Ecological Economics, 64, 245-252. http://dx.doi.org/10.1016/j.ecolecon.2007.09.020

Teasdale, J. R., Coffman, C. B., \& Mangum, R. W. (2007). Potential long-term benefits of no-tillage and organic cropping systems for grain production and soil improvement. Agronomy Journal, 99, 1297-305. http://dx.doi.org/10.2134/agronj2006.0362

Thorup-Kristensen, K., Dresbøll, D. B., \& Kristensen, H. L. (2012). Crop yield, root growth, and nutrient dynamics in a conventional and three organic cropping systems with different levels of external inputs and $\mathrm{N}$ re-cycling through fertility building crops. European Journal of Agronomy, 37, 66-82. http://dx.doi.org/10.1016/j.eja.2011.11.004

Tuck, S. L. Winqvist, C., Mota, F., Ahnström, J., Turnbull, L. A., \& Bengtsson, J. (2014). Land-use intensity and the effects of organic farming on biodiversity: a hierarchical meta-analysis. Journal of Applied Ecology, 51, 746-755. http://dx.doi.org/10.1111/1365-2664.12219

Vaisman, I., Entz, M. H., Flaten, D. N., \& Gulden, R. H. (2011). Blade roller-green manure interactions on nitrogen dynamics, weeds, and organic wheat. Agronomy Journal, 103, 879-89. http://dx.doi.org/10.2134/agronj2010.0437

Wagg, C., Jansa, J., Stadler M., Schmid, B., \& Van Der Heijden, M. G. A. (2011). Mycorrhizal fungal identity and diversity relaxes plant-plant competition. Ecology, 92, 1303-1313. http://dx.doi.org/10.1890/10-1915.1

Widmer, F., Rasche, F., Hartmann, M., \& Fliessbach, A. (2006). Community structures and substrate utilization of bacteria in soils from organic and conventional farming systems of the DOK long-term field experiment. Applied Soil Ecology, 33, 294-307. http://dx.doi.org/10.1016/j.apsoil.2005.09.007

Woodley, A., Audette, Y., Fraser, T., Arcand, M., Voroney, P., Knight, D., \& Lynch, D. H. (2014). Nitrogen and 
Phosphorus Fertility Management in Organic Field Crop Production. In R. C. Martin \& R. MacRae (Eds.), Managing Energy, Nutrients and Pests in Organic Field Crops (pp. 59-106) CRC Press.

Wortman, S., Galusha, T. D., Mason, S. C., \& Francis, C. A. (2011). Soil fertility and crop yields in long-term organic and conventional cropping systems in Eastern Nebraska. Renewable Agriculture and Food Systems, 25, 281-95. http://dx.doi.org/10.1017/S1742170511000317

\section{Copyrights}

Copyright for this article is retained by the author(s), with first publication rights granted to the journal.

This is an open-access article distributed under the terms and conditions of the Creative Commons Attribution license (http://creativecommons.org/licenses/by/3.0/). 